4. Shvorak A. Prirodni kormovi ugiddya ta social'no-ekonomichnij rozvitok sil's'kih teritorij [Shvorak A. Natural forage lands and socio-economic development of rural territories] / Ekonomichnij chasopis Skhidno€vropejs'kogo nacional'nogo universitetu imeni Lesi Ukraïnki: zhurnal / uklad. L. G. Lipich, M. B. Kulinich. Economic Journal of the East-European National University named after Lesia Ukrainka: journal Luc'k : Vezha-Druk, 2018. № 2(14). S. 112-116.

Стаття надійшла до редакції 01.11.2019 p.

кандидат економічних наук, доцент,

Східноєвропейський національний університет імені Лесі Українки, кафедра обліку і аудиту; м. Луцьк; ORCID ID 0000-0002-3393-4016, e-mail: Bukalonadiya@ukr.net

https://doi.org/10.29038/2411-4014-2019-01-128-137

\title{
ЕКОЛОГІЧНІ ВИТРАТИ, ЇХ ЕКОНОМІЧНА ПРИРОДА ТА СТАН
}

У статті розглянуто економічне поняття «екологічні витрати», трактування його різними вітчизняними та закордонними науковцями. Досліджено природу походження екологічних витрат. Розглянуто зміни нормативноправового законодавства щодо обліку витрат на охорону навколишнього природного середовища у сучасних умовах. Проведено аналізування витрат на охорону навколишнього природного середовища у загальному обсязі та за власні кошти підприємств, організацій, установ. Досліджено екологічні витрати за джерелами фінансування в 2017 році. Проведено аналізування капітальних інвестицій на охорону навколишнього природного середовища. Розглянуто проблеми зображення в бухгалтерському обліку та звітності екологічних витрат.

Ключові слова: витрати, екологічні витрати, облік, природоохоронні витрати, екологічний податок, аналіз, інвестиції.

Букало Надежда, кандидат экономических наук, доцент, Восточноевропейский национальный университет имени Леси Украинский, кафедра учета и аудита; г. Луцк; ORCID ID 0000-0002-3393-4016, e-mail:Bukalonadiya@ukr.net

\section{ЭКОЛОГИЧЕСКИЕ РАСХОДЫ, ИХ ЭКОНОМИЧЕСКАЯ ПРИРОДА И СОСТОЯНИЕ}

В статье рассмотрены экономическое понятие «экологические расходы», трактовка его различными отечественными и зарубежными учеными. Исследована природа происхождения экологических издержек. Рассмотрены изменения нормативно-правового законодательства по учету расходов на охрану окружающей среды в современных условиях. Проведен анализ затрат на охрану окружающей среды в общем объеме и за собственные средства предприятий, организаций, учреждений. Исследованы экологические расходы по источникам финансирования в 2017 году. Проведен анализ капитальных инвестиций на охрану окружающей среды. Рассмотрены проблемы изображения в бухгалтерском учете и отчетности экологических издержек.

Ключевые слова: затраты, экологические расходы, учет, природоохранные расходы, экологический налог, анализ, инвестиции.

Bukalo Nadiya

PhD in Economics, Associate Professor, Lesya Ukrainka Eastern European National University, Department of Accounting and Auditing; Lutsk; ORCID ID 0000-0002-3393-4016, e-mail: Bukalonadiya@ukr.net 


\section{ECOLOGICAL COSTS, THEIR ECONOMIC NATURE AND CONDITION}

The article considers the economic concept of «environmental costs», various interpretations of his domestic and foreign scientists. The changes of the normative-legal legislation concerning expenses on protection of the environment in the modern conditions are investigated. Conducting an analysis of the costs of protecting the environment. The problems of reflection in the accounting and reporting of environmental costs are investigated.

The purpose of the article. The purpose of the article. Investigation of the essence, content and role of environmental costs in economic activity, studying the state of expenses on environmental protection in Ukraine.

The method (methodology). In this paper we have used the following methods: the method of comparison,method of analysis, method of synthesis, method of abstraction, theoretical method, method of historical and logical generalization. The dialectical method of investigation has become the methodological basis of the research.

Results. The essence of the economic concept «ecological costs» and their reflection on the legislative and normative basis are revealed.

The analysis of expenses on environmental protection at the expense of own funds of enterprises, organizations, institutions by types of environmental measures in actual prices has been carried out.

The dynamics of capital investments on environmental protection and capital repairs of the main means of environmental protection at the expense of own funds of enterprises, organizations and institutions are researched. The dynamics of current expenses for environmental protection at the expense of own funds of enterprises, organizations, institutions and environmental expenditures by sources of financing in 2017 are considered. The problem of displaying environmental costs in accounting and financial reporting is highlighted.

Further research seems appropriate to focus on the location of environmental costs in management accounting.

Keywords: costs, environmental costs, accounting, environmental costs, analysis, ecological tax investment.

Постановка проблеми. Основними напрямками сучасної соціально-екологічної політики $є$ екологізація суспільного виробництва та забезпечення екологічної безпеки життєдіяльності населення та природних екосистем. Як відомо, будь-яке виробництво пов'язане 3 навколишнім природним середовищем, тобто воно здійснює на нього впливи, як позитивні так і негативні.

У світовому суспільстві та в Україні одне з перших місць займає проблема довкілля, а саме проблема зменшення викидів у довкілля та проблема зниження екологічних витрат на підприємствах.

Аналіз останніх досліджень і публікацій. Питання з бухгалтерського обліку, пов'язаних 3 екологічною діяльністю в різні періоди досліджували такі вчені-економісти, як: І.В. Замула [1], Ф. Ф. Бутинець, Н. М. Малюга, Л. Г. Мельник, Н. Є. Потапенко, Р. Адамс, В. Лень [2], та інші. Зокрема, науковцем О. М. Кондратюк [3] розроблено рекомендації щодо удосконалення обліку і аналізу екологічних витрат промислових підприємств та практичному їх використанні в процесі прийняття управлінських рішень 3 охорони навколишнього природного середовища.

Автор А.В. Гарманов [4] у своїй дисертації визначає екологічні витрати як особливий об'єкт бухгалтерського екологічного обліку та економічного екологічного аналізу й виділяє три групи таких об'єктів: платежі за освоєння, видобуток, використання природних ресурсів та їх відтворення, охорону або природоресурсні платежі; екологічні платежі; природоохоронні витрати.

Такими авторами, як I.В. Замула та М.M. Шигун [5] запропоновано в залежності від виду діяльності екологічні витрати розділити на операційні та інвестиційні, з чим ми погоджуємося.

Не дивлячись на значні напрацювання та цінність результатів цих досліджень, питання щодо сутності екологічних витрат їх стану на сучасному етапі мають дискусійний характер, що й обумовило мету дослідження.

Постановка завдання. Проведення аналізу підходів визначення поняття «екологічні витрати» та їх значення. Дослідження нормативно-правових актів регулювання обліку екологічних витрат в Україні на сучасному етапі. Проведення аналізування витрат на охорону навколишнього природного середовища.

Виклад основного матеріалу. Угоди про асоціацію між Україною та Європейським союзом та його державами-членами відкриває нові можливості та створює нові стандарти у різних сферах суспільного життя, включаючи й сферу охорони довкілля.

Екологічна діяльність на підприємстві пов'язана, насамперед, 3 відповідними витратами, доходами та зобов'язаннями які впливають на економічні показники роботи підприємства. Це зумовлює сьогодні вести бухгалтерський облік екологічних наслідків. Виокремлення доходів, витрат, зобов'язань що пов'язані з природоохоронними заходами призведе до достеменних облікових даних про розміри, напрями та їх види. 
Екологічні витрати виникають у процесі діяльності підприємства (операційної, інвестиційної) i пов'язані з використанням природних ресурсів та їх охороною.

Грунтовні дослідження праць вітчизняних учених щодо витрат пов'язаних з екологічною діяльністю показали різноманітні категорії таких визначень: «природоохоронні витрати», «витрати на охорону довкілля», «витрати на охорону навколишнього природного середовища», «екологічні витрати».

Такі науковці, як В. Лень, О. Колівешко [2] окрім трактування терміну «екологічні витрати», розтлумачують «екологічні втрати» та «екологічні збитки». Під екологічними втратами для цілей бухгалтерського обліку, на погляд науковців, варто розуміти зменшення вартості активів підприємства без перенесення іiі на продукт виробництва та без їх вибуття за його межі за рішенням власника, яке відбувається внаслідок несприятливих стихійних явищ та негативного антропогенного впливу на природне середовище. Поняття «екологічні збитки» містить інформацію про господарські операції та іншу інформацію про негативні зміни стану довкілля і вплив цих змін на виробничу та соціальну сфери.

Так, природоохоронні витрати, за твердженням С.В. Макар [6, с. 12] - це суспільно необхідні витрати на підтримку якості навколишнього середовища, на будь-які форми та види господарської діяльності чи загальну підтримку природно-ресурсного потенціалу, зокрема збереження екологічної рівноваги на всіх рівнях - від локального до глобального. Витрати на охорону довкілля, за баченням А.Н. Брилєва [7, с. 7] - витрати з усунення негативного впливу сучасного виробництва на довкілля і життєдіяльність людини та з відновлення раніше порушених природних об'єктів.

Витрати на охорону навколишнього природного середовища - фактичні витрати на охорону навколишнього природного середовища, направлені на запобігання або зведення до мінімуму збитку якості навколишнього природного середовища, а також необхідні витрати на усунення негативних наслідків (збитку) погіршення якості навколишнього природного середовища або компенсації за них.

На сьогодні в економічній літературі України наводиться достатньо різноманітних визначень категорії «екологічні витрати», але часто ці визначення є неоднозначними і розглядають таку категорію з різних точок зору. Для усвідомлення проблематики формування, ідентифікації та відображення екологічних витрат підприємства необхідно визначитися з їхньою сутністю (табл. 1).

\section{Таблиия 1}

\section{Сутність економічної категорії «екологічні витрати»}

\begin{tabular}{|l|l|}
\hline \multicolumn{1}{|c|}{ Автор } & \multicolumn{1}{|c|}{ Сутність екологічних витрат } \\
\hline Замула І.В. [1] & всі витрати, пов'язані зі здійсненням екологічної діяльності підприємств \\
\hline Максимів Л.І. [8] & $\begin{array}{l}\text { витрати на покриття негативних зовнішніх ефектів, які виникають внаслідок } \\
\text { добровільних чи обов'язкових природоохоронних заходів з метою запобігання, } \\
\text { усунення чи зменшення навантажень на довкілля, а також внаслідок втрат } \\
\text { продуктивнсті та незворотних втрат сировини, матеріалів, енергії }\end{array}$ \\
\hline Саєнко, К.С. [9] & $\begin{array}{l}\text { витрати на придбання ліцензії на право користування надрами; витрати на } \\
\text { освоєння природних ресурсів; плата за негативний вплив на навколишнє } \\
\text { середовище; капітальні і поточні витрати природоохоронної діяльності }\end{array}$ \\
\hline В. Лень, О. Колівешко [2] & $\begin{array}{l}\text { сукупність витрат за користування надрами та іншими природними ресурсами, } \\
\text { плату за видобування корисних копалин, екологічний податок та витрати на } \\
\text { природоохоронні заходи }\end{array}$ \\
\hline Слюсарчук Р. І. [10] & $\begin{array}{l}\text { сукупність живої та уречевленої праці, яка витрачається на відтворення } \\
\text { природних ресурсів і природного довкілля, попередження і ліквідацію } \\
\text { забруднення довкілля, підтримання в нормальному стані і покращення якості } \\
\text { природних ресурсів, а також майбутньої праці, яка буде витрачатися на } \\
\text { усунення негативних економічних, екологічних і соціальних наслідків, що } \\
\text { викликані теперішнім забрудненням і нераціональним використанням } \\
\text { природних ресурсів }\end{array}$ \\
\hline Туниця Ю.Ю. с. [11]. & $\begin{array}{l}\text { сукупність живої та уречевленої праці, яка витрачається на відтворення } \\
\text { природних ресурсів і природного довкілля, попередження і ліквідацію } \\
\text { забруднення довкілля, підтримання в нормальному стані і покращення якості } \\
\text { природних ресурсів, а також майбутньої праці, яка буде витрачатися на } \\
\text { усунення негативних економічних, екологічних і соціальних наслідків, що } \\
\text { викликані теперішнім забрудненням і нераціональним використанням } \\
\text { природних ресурсів }\end{array}$ \\
\hline
\end{tabular}


За нормативним визначенням до витрат на охорону навколишнього природного середовища належать всі види витрат, спрямовані на запобігання, скорочення чи ліквідацію забруднення, інших видів шкідливого впливу господарської та іншої діяльності на навколишнє природне середовище, при наданні послуг чи використанні продукції, а також на збереження біорізноманіття та середовища існування.

На нашу думку під екологічними витратами можна розуміти всі витрати пов’язані із здійсненням екологічної діяльності: витрати за користування всіма природними ресурсами, витрати на охорону навколишнього природного середовища, витрати на усунення негативних наслідків, витрати на дослідження та відтворення природних ресурсів.

Отже, категорія екологічних витрат стосується багатьох аспектів:

- витрати на охорону атмосферного повітря і проблеми зміни клімату;

- витрати на очищення зворотних вод;

- витрати на поводження з відходами, у тому числі за окремими напрямами;

- витрати на захист і реабілітацію грунту, підземних і поверхневих вод;

- витрати на зниження шумового і вібраційного впливу (за винятком заходів для охорони праці);

- витрати на збереження біорізноманіття і середовища існування;

- витрати на забезпечення радіаційної безпеки (за винятком заходів для запобігання аваріям і катастрофам);

- витрати на науково-дослідні роботи природоохоронного спрямування, у тому числі за окремими напрямами;

- інші витрати на охорону навколишнього природного середовища.

Цікавою є думка авторів [12] щодо віднесення до екологічних витрат і окремо виділити витрати на придбання екологічно чистої сировини; оплату праці за виконану роботу пов' язану з охороною навколишнього середовища; амортизаційні відрахування природоохоронного устаткування; пені, штрафи, виплачені державі за наднормативні викиди речовин що забруднюють; пені за прострочені позики, видані на природоохоронні цілі; збитки від продажу, вибуття об'єктів основних засобів, пов' язаних із природоохоронною діяльністю; інші витрати на охорону навколишнього середовища.

Огляд законодавчо-нормативної бази та економічної літератури з приводу зображення природоохоронної діяльності України, віднесення тих чи інших витрат до природоохоронних в обліку та звітності, сплати екологічного податку та ренти:

- Закон України «Про охорону навколишнього природного середовища» від 25 червня 1991 року №1264-XII в (зі змінами від 12.10.2018) - Закон визначає правові, економічні та соціальні основи організації охорони навколишнього природного середовища в інтересах нинішнього i майбутніх поколінь;

- Постанова КМУ «Перелік видів діяльності, що належать до природоохоронних заходів» від 17.09.96 р., № 1147 (зі змінами від 18.12.2018 N 1131) - містить перелік видів діяльності;

- Рекомендація про порядок складання статистичного звіту за формою 1 - екологічні витрати «Витрати на охорону навколишнього природного середовища та екологічні платежі» затверджено наказом Держстату від 30.09.2015 N 259 - містять поняття та визначення, роз'яснення щодо окремих показників та змісту форми № 1-екологічні витрати;

- Наказ Державного агентства лісових ресурсів України «Про затвердження Методичних рекомендацій з формування собівартості продукції (робіт, послуг) на підприємствах, що належать до сфери управління Державного агентства лісових ресурсів України» від 14.05.2013 p. №124 - мета забезпечити єдині засади формування собівартості продукції (робіт, послуг) лісового господарства та промисловості на підприємствах, що належать до сфери управління Державного агентства лісових ресурсів України;

- Наказ Мінфіну «Про затвердження Методичних рекомендацій зі складання звіту про управління» від 07.12.2018 № 982 (розділ «екологічні аспекти»). За напрямом «Екологічні аспекти» наводиться інформація щодо впливу діяльності підприємства на навколишнє середовище, залежно від галузі, в якій функціонує підприємство та від заходів з охорони довкілля і зменшення впливу діяльності підприємства на навколишнє середовище;

- Податковий кодекс України від 23.12.2010 № 2856-VI - розділ VIII Екологічний податок, розділ IX Рентна плата - порядок нарахування податків та зборів;

- Про затвердження форми Податкової декларації екологічного податку затверджена наказом Мінфіну від 17.08.2015 №715. - податкове зобов’язання з екологічного податку. Варто зазначити, що 
в Європейських країнах головним документом екологічної звітності підприємства виступає екологічна декларація, яка є наслідком проведення екологічного аудиту;

- Податкова декларація з рентної плати затверджена наказом Мінфіну від 17 серпня 2015 року № 719 рентна плата за користування природними ресурсами.

За Планом рахунків бухгалтерського обліку активів, капіталу, зобов'язань і господарських операцій підприємств і організацій та національними положеннями (стандартами) бухгалтерського обліку, окремий облік екологічних витрат не передбачено.

Охорона навколишнього природного середовища, раціональне використання природних ресурсів, забезпечення екологічної безпеки життєдіяльності людини - невід'ємна умова сталого економічного та соціального розвитку України, а екологічні заходи підприємства та ефективний режим роботи позитивно впливає і мінімізує шкідливий вплив на довкілля.

Дослідження щодо витрат на охорону навколишнього природного середовища за рахунок власних коштів підприємств, організацій, установ за видами природоохоронних заходів у 2017 р. у фактичних цінах представлено у табл. 2. Виходячи із необхідності адекватного, повного і комплексного відображення сукупності природоохоронних робіт, за основу доцільно прийняти групування за видами та напрямками витрат.

Протягом 2017 р. витрати на охорону навколишнього природного середовища підприємствами, організаціями та установами України було витрачено 24246,6 млн грн. Найбільшу питому вагу з них склали витрати на очищення зворотних вод $35,25 \%$ та поводження 3 відходами $-34,3 \%$. Основні напрямки використання коштів природоохоронних фондів вказують на основні екологічні проблеми держави - це охорона та покращення стану водних ресурсів та раціональне поводження з відходами. Витрати на капітальний ремонт основних засобів природоохоронного призначення охорони атмосферного повітря і проблеми зміни клімату склали 293,3 млн грн.

Таблиия 2

Витрати на охорону навколишнього природного середовища за власні кошти підприємств, організацій, установ за видами природоохоронних заходів у 2017 p.

у фактичних цінах, млн грн

\begin{tabular}{|c|c|c|c|c|c|}
\hline \multirow[b]{3}{*}{ Показник } & \multirow[b]{3}{*}{ 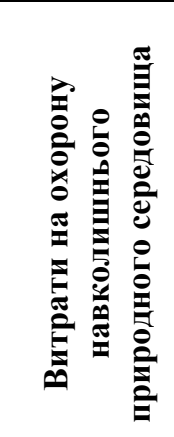 } & \multirow[b]{3}{*}{ 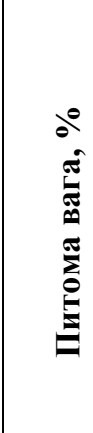 } & \multicolumn{3}{|c|}{ У тому числі } \\
\hline & & & \multicolumn{2}{|c|}{ капітальні інвестиції } & \multirow[b]{2}{*}{ 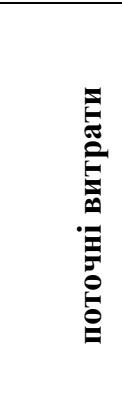 } \\
\hline & & & $\begin{array}{l}0 \\
\dot{0} \\
\stackrel{0}{0} \\
\dot{D}\end{array}$ & 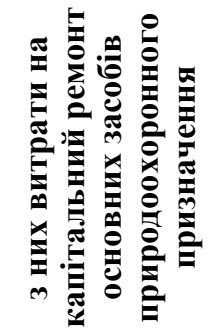 & \\
\hline 1 & 2 & 3 & 4 & 5 & 6 \\
\hline Усього & 24246,6 & 100 & 5132,1 & 632,8 & 19114,5 \\
\hline $\begin{array}{l}\text { Охорона атмосферного повітря і проблеми } \\
\text { зміни клімату }\end{array}$ & 4670,9 & 19,3 & 2586,5 & 293,3 & 2084,4 \\
\hline Очищення зворотних вод & 8535,9 & 35,2 & 556,3 & 241,5 & 7979,6 \\
\hline Поводження з відходами & 8318,9 & 34,3 & 1081,9 & 42,0 & 7237,0 \\
\hline $\begin{array}{l}\text { Захист і реабілітація грунту, підземних і } \\
\text { поверхневих вод }\end{array}$ & 1695,2 & 7,0 & 738,7 & 26,3 & 956,5 \\
\hline Зниження шумового і вібраційного впливу & 28,0 & 0,1 & 21,7 & 21,5 & 6,3 \\
\hline $\begin{array}{l}\text { Збереження біорізноманіття і середовища } \\
\text { існування }\end{array}$ & 521,1 & 2,1 & 10,6 & 2,0 & 510,5 \\
\hline Радіаційна безпека & 163,7 & 0,7 & 116,5 & 0,2 & 47,2 \\
\hline $\begin{array}{l}\text { Науково-дослідні роботи природоохоронного } \\
\text { спрямування }\end{array}$ & 32,9 & 0,1 & 3,6 & 0,2 & 29,3 \\
\hline Інші види природоохоронної діяльності & 280,0 & 1,2 & 16,3 & 5,8 & 263,7 \\
\hline
\end{tabular}

Сформовано на основі джерела [13] 
В процесі аналізу капітальних інвестицій на охорону навколишнього природного середовища за 2010-2017 роки (рис.1) виявлено, що інвестиції на охорону навколишнього природного середовища власними коштами підприємств, організацій у 2017 р. у порівнянні 32010 роком зросли у двічі. Частка таких інвестицій від загального обсягу коливалася в межах від 29,1 до 77,7 \%. Це не повною мірою сприяє формуванню ресурсної бази модернізації, реконструкції та технічного переоснащення об'єктів природоохоронної інфраструктури й може призвести до незворотних негативних впливів на довкілля.

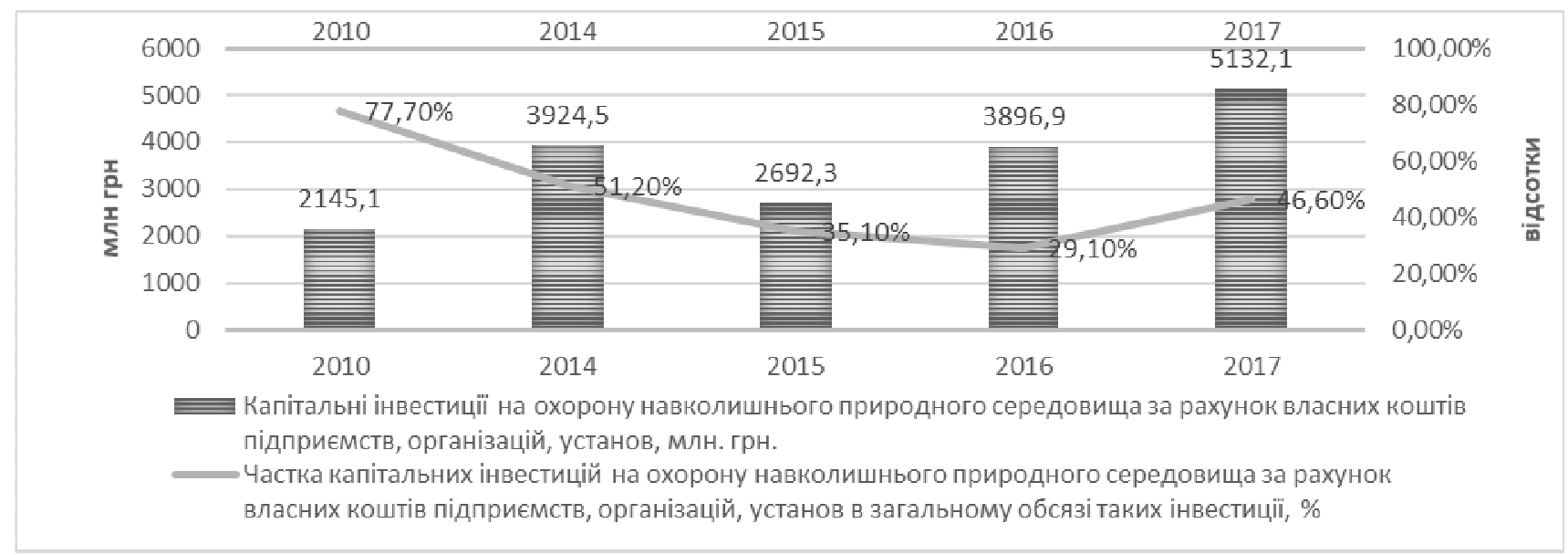

Рис. 1. Капітальні інвестиції на охорону навколишнього природного середовища

Сформовано на основі джерела [13]

Згідно зі статистичними даними, за період 2010-2017 рр. кількість інвестиції в капітальний ремонт основних засобів природоохоронного призначення за рахунок власних коштів підприємств, організацій, установ за регіонами коливається залежно від періоду. Частка таких інвестицій в загальному обсязі має тенденцію до зменшення (рис. 2).

За даними Держкомстату України, щороку зростають поточні витрати на охорону навколишнього природного середовища по Україні за рахунок власних коштів підприємств, організацій, установ. Частка таких витрат від загального обсягу поточних природоохоронних витрат за всі досліджувані роки понад $93 \%$ (рис. 3).

Збільшення масштабів експлуатації природних ресурсів і посиленням деструктивних змін довкілля, впровадження екологічних заходів зумовлює необхідність пропорційного, збільшення витрачання коштів і матеріальних засобів на екологічні цілі.

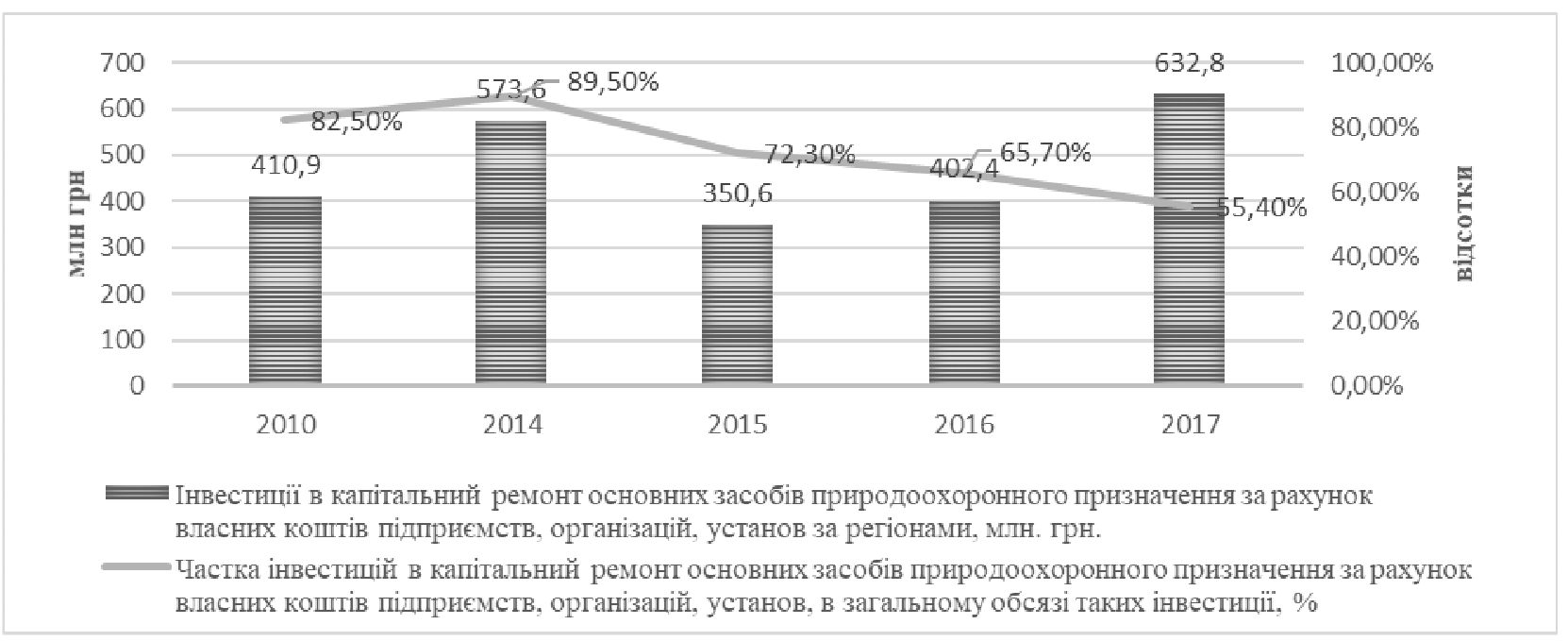

Рис. 2. Інвестииї в капітальний ремонт основних засобів природоохоронного призначення

Сформовано на основі джерела [13] 


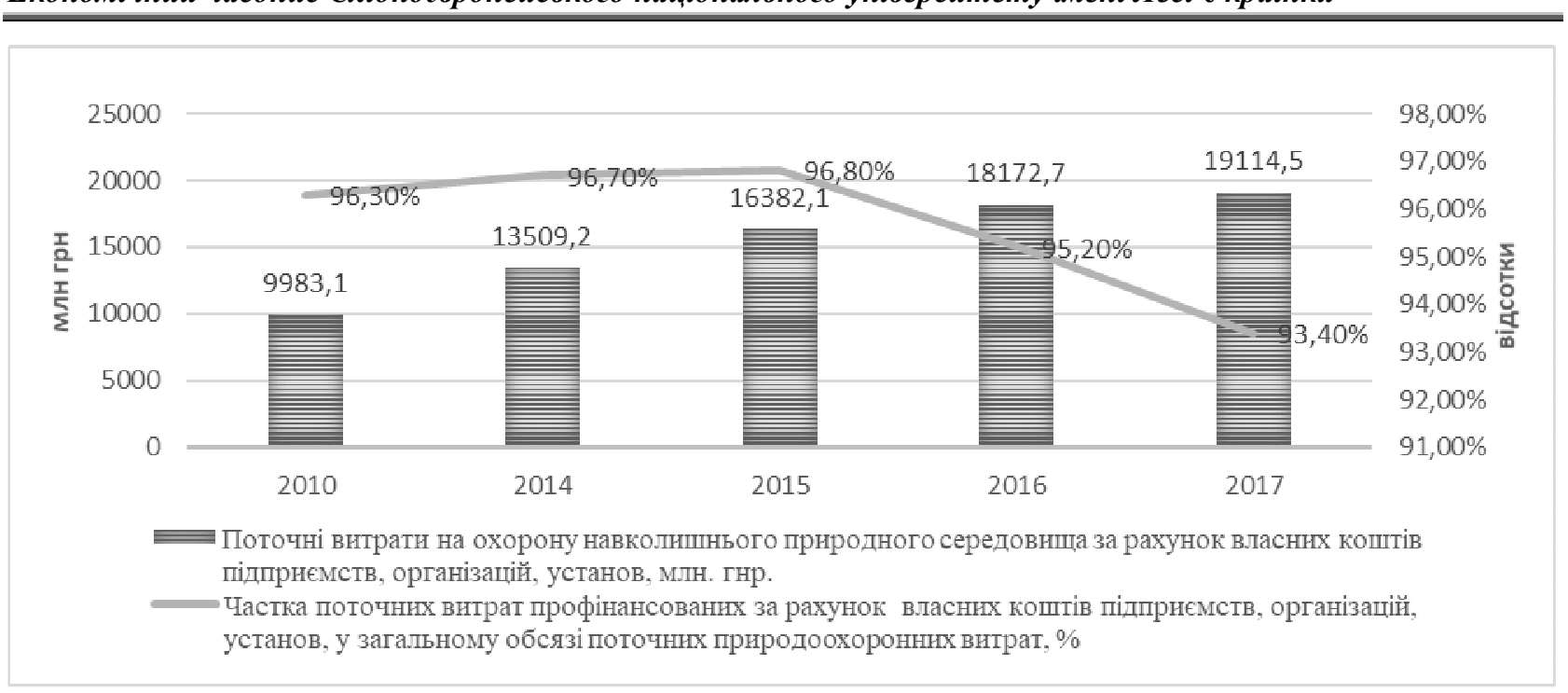

Рис. 3. Динаміка поточних витрат на охорону навколищнього природного середовища

Сформовано на основі джерела [13]

Істотну позитивну роль в інформаційно-аналітичному забезпеченні управлінських рішень у сфері охорони довкілля й раціонального природокористування відіграє структуризація екологічних витрат за джерелами фінансування (рис. 4).

Дослідження екологічних витрат за джерелами фінансування у 2017 р. показало, що коштами місцевих бюджетів було профінансовано лише 8,2 \% таких витрат. Найбільша частка витрат на охорону навколишнього природного середовища припадає на витрати власних коштів підприємств та організацій - 77,0 \%, інші джерела фінансування склали $14,8 \%$.

Як показало дослідження найбільша частка екологічних витрат сформована власними коштами підприємств, організацій, установ за регіонами. Тому доцільно такі витрати окремо показувати в обліку та звітності підприємств.

Бухгалтерський облік, на сьогодні не здатен враховувати екологічний вплив підприємства, установ, організацій на навколишнє природне середовище та інформаційно забезпечити на належному рівні екологічне управління.

Існує низка перешкод, щодо організації екологічного обліку та подання звітності по природоохоронних заходах:

- відсутній стимул ураховувати зобов'язання через необхідність вираховувати витрати з доходу, що оподатковується після їх здійснення;

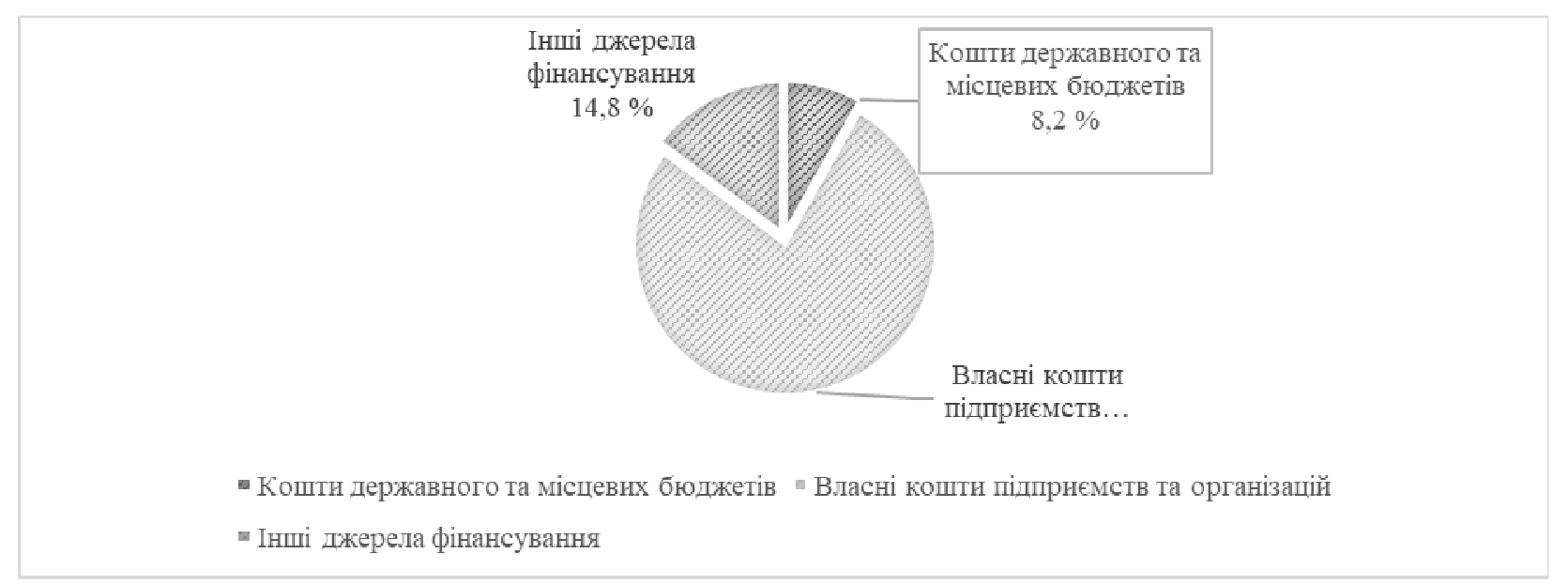

Рис. 4 Структура екологічних витрат за джерелами фінансування у 2017 рочі

Сформовано на основі джерела [13] 
- надмірна складність виділення витрат на природоохоронну діяльність із суми загальних витрат;

- відсутність конкретних рекомендацій відносно надання інформації про природоохоронну діяльність і організацію екологічного обліку на підприємствах;

- відсутність методики прийняття рішень стосовно зниження та попередження екологічних ризиків $[14 ; 15 ; 16]$;

- недостатнє нормативно-правове регулювання питань, пов’язаних з інформаційним забезпеченням управління охороною навколишнього середовища, раціонального природокористування та екологічної безпеки господарчих суб' єктів;

- облік та списання екологічних витрат ведеться безсистемно та за загальною методикою без врахування їх особливостей;

- екологічні витрати не показуються окремо, а повністю відносяться до собівартості виробленої продукції;

- відсутність інформації у фінансовій звітності про екологічні витрати, екологічні доходи та зобов' язання;

- відсутність конкретних рекомендацій щодо організації екологічного обліку на підприємствах.

Для вирішення завдань регіональної екологічної політики необхідно здійснювати скоординовані дії за такими основними напрямками:

- затвердження додаткової системи плану рахунків і регістрів аналітичного обліку щодо екологічних витрат, екологічних доходів та зобов'язань;

- внесення змін у національні положення (стандарти) бухгалтерського обліку інформації щодо екологічних витрат, екологічних доходів та зобов'язань;.

- врахування в обліковій політиці підприємства (пов'язаних з екологічною діяльністю) особливостей його господарської діяльності при визначенні екологічних витрат;

- збоку держави - вдосконалення нормативно-правової бази, що базується на міжнародних стандартах та ін.

Висновки. Отже, охорона навколишнього природного середовища, раціональне використання природних ресурсів, забезпечення екологічної безпеки життєдіяльності людини - необхідна умова сталого економічного та соціального розвитку України. Екологічна діяльність підприємства пов'язана 3 відповідними витратами, які прямо чи опосередковано впливають на економічні показники діяльності підприємства. Сьогоднішній бухгалтерський облік не здатний враховувати екологічний вплив підприємства на навколишнє природне середовище. Тому постає необхідність в удосконаленні законодавчо-нормативної бази системи бухгалтерського обліку.

Подальше дослідження бачиться доречним направити на визначення екологічних витрат в управлінському обліку.

\section{Джерела та література}

1. Замула I. В. Бухгалтерський облік екологічної діяльності у забезпеченні стійкого розвитку економіки [Текст] : монографія. Житомир : ЖДТУ, 2010. 440 с.

2. Лень В., О. Колівешко Екологічні збитки, витрати та втрати: поняття, зміст. Бухгалтерський облік $i$ aydum. 2014. № 2. C. 11-18.

3. Кондратюк О.М. Облік і аналіз екологічних витрат промислових підприємств: дис. ... канд. екон. наук: 08.00.09 / О. М. Кондратюк. Київ, 2008. 260 с.

4. Гарманов А. В. Организация экономического экологического анализа хозяйствующего субъекта: автореф. дис. на соискание научн. степени канд. экон. наук: спец. 08.00.12 «Бухгалтерский учет, статистика». Воронеж, 2011. $-20 \mathrm{c}$.

5. Замула I. В., Шигун М. М. Аналітична модель бухгалтерського обліку екологічної діяльності. Вісник наиіонального університету «Львівська політехніка». 2009. № 647. С. 337-343.

6. Макар С.В. Основы экономики природопользования : пер. с англ.. Конференция ООН по торговле и развитию : сб. докладов. Москва: Изд-во «Финансы и статистика», 1997. 200 с.

7. Брылев А. Н. Пути совершенствования учета и анализа затрат на охрану окружающей среды : автореф. дисс. на соискание учен. степени канд. экон. наук. Львів, 1983. 20 с.

8. Максимів Л .І. Тенденції розвитку екологічно орієнтованого бухгалтерського обліку. Бухгалтерський облік і аудит : наук. журнал. 2005. № 5. С. 18-23. 
9. Саенко К. С. Учет экологических затрат. Москва: Финансы и статистика, 2005. 376 с.

10. Слюсарчук Р. І. Класифікація екологічних витрат і джерела їх виникнення на деревообробних підприємствах. Науковий вісник Укр. ДЛТУ, 2003, вип. 13.4. С 234-238.

11. Екологічна Конституція Землі. Методологічні засади. / за ред. акад. НАН України, д-ра екон. наук, проф. Ю. Ю. Туниці. Львів: РВВ НЛТУ України, 2011. 440 с

12. Савченко О. Ф., Дацій О. І., Байда А. О., Зима Г. І. Екологічні витрати: проблеми права, обліку та оподаткування. Економіка та держава, 2015. № 5. C. 11-19. URL: http://www.economy.in.ua/pdf/5_ 2015/ 4.pdf (дата звернення: 14.02.19).

13. Статистичний збірник.. Довкілля України за 2017 рік. За редакцією О. М. Прокопенко. Київ: 2018.225 с. URL: http://www.ukrstat.gov.ua/druk/publicat/kat_u/2018/zb/11/zb_du2017.pdf

14. Гриценко О. І. Екологічний облік: визначення перспектив та основних засад упровадження. Випуск \# 2 / 2016. URL: http://www.economyandsociety.in.ua/journal/2_ukr/121.pdf.

15. Букало Н. А. Витрати підприємства як об'єкт управлінського обліку / Н. А. Букало // Вісн. Одес. нац. ун-ту. Серія: Економіка / Одес. нац. ун-т ім. І. І. Мечникова. Одеса, 2017. Т. 22, № 1(54). С. 166-169.

16. Фатенок-Ткачук А. О., Блаженчук В. С. Проблеми обліку екологічних витрат підприємств. URL: http://www.easterneurope-ebm.in.ua/journal/14_2018/72.pdf.

\section{References}

1. Zamula, I. V. (2010). Bukhhalterskyi oblik ekolohichnoi diialnosti u zabezpechenni stiikoho rozvytku ekonomiky [Accounting of ecological activity in ensuring sustainable development of the economy] [Tekst] : monohrafiia. Zhytomyr : ZhDTU, 440 s. [in Ukrainian].

2. Len, V. (2014). Ekolohichni zbytky, vytraty ta vtraty: poniattia, zmist. [Environmental damage, costs and losses: concept, content] Bukhhalterskyi oblik i audyt. 2, S. 11-18. [in Ukrainian].

3. Kondratiuk, O. M. (2008). Oblik i analiz ekolohichnykh vytrat promyslovykh pidpryiemstv [Облік і аналіз екологічних витрат промислових підприємств]: Dys. ... kand. ekon. nauk: 08.00.09. K., 260 s. [in Russian].

4. Harmanov, A. V. (2011). Orhanyzatsyia эkonomycheskoho эkolohycheskoho analyza khoziaistvuiushcheho subъekta [Organization of economic ecological analysis of the economic entity]: avtoref. dys. na soyskanye nauchn. stepeny kand. эkon. nauk: spets. 08.00.12 «Bukhhalterskyi uchet, statystyka». Voronezh, 20 s. [in Russian].

5. Zamula, I. V. \& Shyhun, M.M. (2009). Analitychna model bukhhalterskoho obliku ekolohichnoi diialnosti [Analytical model of accounting for environmental activities]. Visnyk natsionalnoho universytetu «Lvivska politekhnika». № 647, S. 337-343. [in Ukrainian].

6. Makar, S. V. (1997). Osnovы эkonomyky pryrodopolzovanyia [Fundamentals of environmental economics] : per. s anhl. Konferentsyia OON po torhovle y razvytyiu : sb. dokladov. M.: Yzd-vo «Fynansы y statystyka», 200 s. [in Russian].

7. Brыlev, A.N. (1983). Puty sovershenstvovanyia ucheta y analyza zatrat na okhranu okruzhaiushchei sredы [Ways to improve accounting and analysis of costs for environmental protection]: avtoref. dyss. na soyskanye uchen. stepeny kand. эkon. nauk. L., 20 s. [in Russian].

8. Maksymiv, L. I. (2005). Tendentsii rozvytku ekolohichno oriientovanoho bukhhalterskoho obliku [Trends in the development of environmentally-oriented accounting]. Bukhhalterskyi oblik i audyt : nauk. zhurnal. № 5, S. 18-23. [in Ukrainian].

9. Saenko, K. S. (2005). Uchte эkolohycheskykh zatrat [Accounting for environmental costs] [Tekst]. M.: Fynansы y statystyka, 376 s. [in Russian].

10. Sliusarchuk, R. I. (2003). Klasyfikatsiia ekolohichnykh vytrat i dzherela yikh vynyknennia na derevoobrobnykh pidpryiemstvakh.[ Classification of environmental costs and sources of their occurrence in woodworking enterprises]. Naukovyi visnyk Ukr. DLTU, [13.4], S 234-238. [in Ukrainian].

11. Ekolohichna Konstytutsiia Zemli. Metodolohichni zasady (2011). [Ecological Constitution of the Earth. Methodological foundations.] / Za red. akad. NAN Ukrainy, d-ra ekon. nauk, prof. Yu.Yu. Tunytsi. Lviv: RVV NLTU Ukrainy, $440 \mathrm{~s}$ [in Ukrainian].

12. Savchenko, O. F. \& Datsii, O.I. \& Baida, A. O. \& Zyma, H. I. (2015). Ekolohichni vytraty: problemy prava, obliku ta opodatkuvannia. [Environmental costs: problems of law, accounting and taxation]. Ekonomika ta derzhava, 2015 № 5. S. 11-19 [Elektronnyi resurs]. - Rezhym dostupu: http://www.economy.in.ua/ pdf/5_2015/4.pdf [in Ukrainian].

13. Statystychnyi zbirnyk. (2018). Dovkillia Ukrainy za 2017 rik. [Environment of Ukraine for 2017.]. Za redaktsiieiu O. M. Prokopenko. K:, 225 s. [Elektronnyi resurs]. Rezhym dostupu: http://www.ukrstat. gov. ua/druk/publicat/kat_u/2018/zb/11/zb_du2017.pdf [in Ukrainian].

14. Hrytsenko O. I. (2016). Ekolohichnyi oblik: vyznachennia perspektyv ta osnovnykh zasad uprovadzhennia. [Environmental accounting: definition of the prospects and the main principles of implementation]. Vypusk \# 2 / 
2016. [Elektronnyi resurs]. Rezhym dostupu: http://www.economyandsociety.in.ua/journal/2_ukr/121.pdf [in Ukrainian].

15. Bukalo N. A. (2017). Vytraty pidpryiemstva yak ob'iekt upravlinskoho obliku. [Expenses of the enterprise as an object of management accounting]. Visn. Odes. nats. un-tu. Seriia: Ekonomika / Odes. nats. un-t im. I. I. Mechnykova. Odesa, T. 22, № 1[54], S. 166-169. [in Ukrainian].

16. Fatenok-Tkachuk, A. O. \&. Blazhenchuk, V. S. Problemy obliku ekolohichnykh vytrat pidpryiemstv. [Problems of accounting of environmental costs of enterprises]. [Elektronnyi resurs]. Rezhym dostupu: http://www. easterneurope-ebm.in.ua/journal/14_2018/72.pdf [in Ukrainian].

Стаття надійшла до редакції 15.02.2019 р. 